\title{
Identifikasi Sebaran Bijih Besi di Daerah Gurun Datar Kabupaten Solok Sumatera Barat Menggunakan Metode Geomagnet
}

\author{
Muh. Ishak Jumarang1)*, Zulfian'1) \\ 1) Jurusan Fisika, FMPA, Universitas Tanjungpura Pontianak \\ Jl. Ahmad Yani, Pontianak, Kalimantan Barat \\ *E-mail: ishakjumarang@yahoo.com
}

\begin{abstract}
Abstrak
Telah dilakukan penelitian sebaran bijih besi di daerah Gurun Datar. Daerah ini merupakan daerah perbukitan yang dilewati oleh jalur sesar Sumatera. Metode yang digunakan adalah metode geomagnet. Berdasarkan pengolahan data diduga terdapat batuan hematit dengan nilai suseptibilitas antara 0,0100 s.d 0,0356 SI pada 29 titik dan urat mineral magnetit pada hematit dengan nilai suseptibilitas antara 0,0600 s.d 0,1753 SI di 5 titik. Nilai korelasi antara data obsevasi dan data kalkulasi berkisar 0,84 s.d 0,99.
\end{abstract}

Kata Kunci: bijih besi, Gurun Datar, metode geomagnet, suseptibilitas.

\begin{abstract}
The research to determine the distribution of iron ore in Gurun Datar has been conducted. This area is a hilly area that is passed by the Sumatran fault line. The method used is geomagnetic method. From the data it can be shown that the suspected hematite rock lies between susceptibility's values of 0,0100 - 0,0356 SI on 29 points of observation and the mineral magnetite in the hematite veins lies between susceptibility's value of 0,0600 - 0,1753 SI found on 5 points of observation. Correlation value between observation data and calculated data is $0,84-0,99$.
\end{abstract}

Keyword: iron ore, Gurun Datar, geomagnetic method, susceptibility.

\section{Pendahuluan}

Mineral bijih besi yang terdapat di alam umumnya ditemukan berasosiasi dengan mineral logam lain, jarang didapatkan dalam keadaan bebas. Walaupun demikian, singkapan mineral bijih besi masih ditemukan di beberapa tempat. Singkapan dan sebaran bijih besi yang tersebar secara acak dapat diketahui dengan menggunakan metode geofisika.

Metode geofisika yang sering digunakan untuk eksplorasi bijih besi adalah metode geolistrik dan magnetik. Metode geolistrik dilakukan untuk menyelidiki keadaan bawah permukaan bumi berdasarkan perbedaan nilai resistivitas mineral, sedangkan metode geomagnet berdasarkan nilai suseptibilitas. Jangkauan kedalaman metode geolistrik hanya berkisar 30 - 45 meter di bawah permukaan bumi. Metode geomagnet cocok dipakai dalam ekplorasi mineral-mineral yang bersifat magnetik. Metode ini bisa dilakukan di darat, di udara dan di laut dengan mengukur sebaran medan magnet bumi.

Kajian mengenai eksplorasi mineral magnetik dengan metode magnetik di daerah Sumatera telah banyak dilakukan diantaranya oleh Zaenudin, dkk (2008) di daerah Gunung Peben P. Belitung, Idral (2007) di Kec. Lembah Gumanti. Sedangkan Mufit, dkk (2006) mengkaji sifat magnetik pasir besi di Pantai Sunur, Pariaman melalui uji laboratorium.

Pada penelitian ini metode magnetik akan diaplikasikan untuk pendugaan potensi biji besi di daerah Gurun Datar Nagari Simpang Tanjung Nan IV Kec. Danau Kembar Kab. Solok, Sumatra Barat. Daerah ini dipilih karena berdasarkan hasil observasi di lapangan, diketahui bahwa di daerah tersebut terdapat singkapan bijih besi yang cukup besar. Singkapan tersebut berwarna hitam kemerahan yang diduga sebagai hematit.

\section{Metode Penelitian \\ 2.1 Pengambilan Data}

Data yang digunakan merupakan data primer yaitu data medan magnet bumi yang diukur di lokasi penelitian. Beberapa peralatan yang digunakan selama penelitian ini adalah seperangkat overhouser magnetometer, tali sepanjang $30 \mathrm{~m}$, GPS (Global Positioning System) Garmin 60CSx, kompas dan parang.

Lokasi penelitian terletak di koordinat 01'04'8,9" - 01'04'18,3" LS dan 100'43'24,3” - 100॰43'34,1" BT. Lokasi penelitian berada pada ketinggian 1350-1500 meter dari permukaan laut (BNPB). Selanjutnya lokasi penelitian dibagi menjadi lintasan 
pengambilan data dengan arah Selatan - Utara sebanyak 4 lintasan dan arah Barat - Timur sebanyak 1 lintasan. Lintasan 1 s.d 4 panjangnya 300 meter dengan jarak antar lintasan 100 meter, sedangkan lintasan 5 hanya berjarak 50 meter. Bentuk Lintasan penelitian direpresentasikan pada Gambar 1:

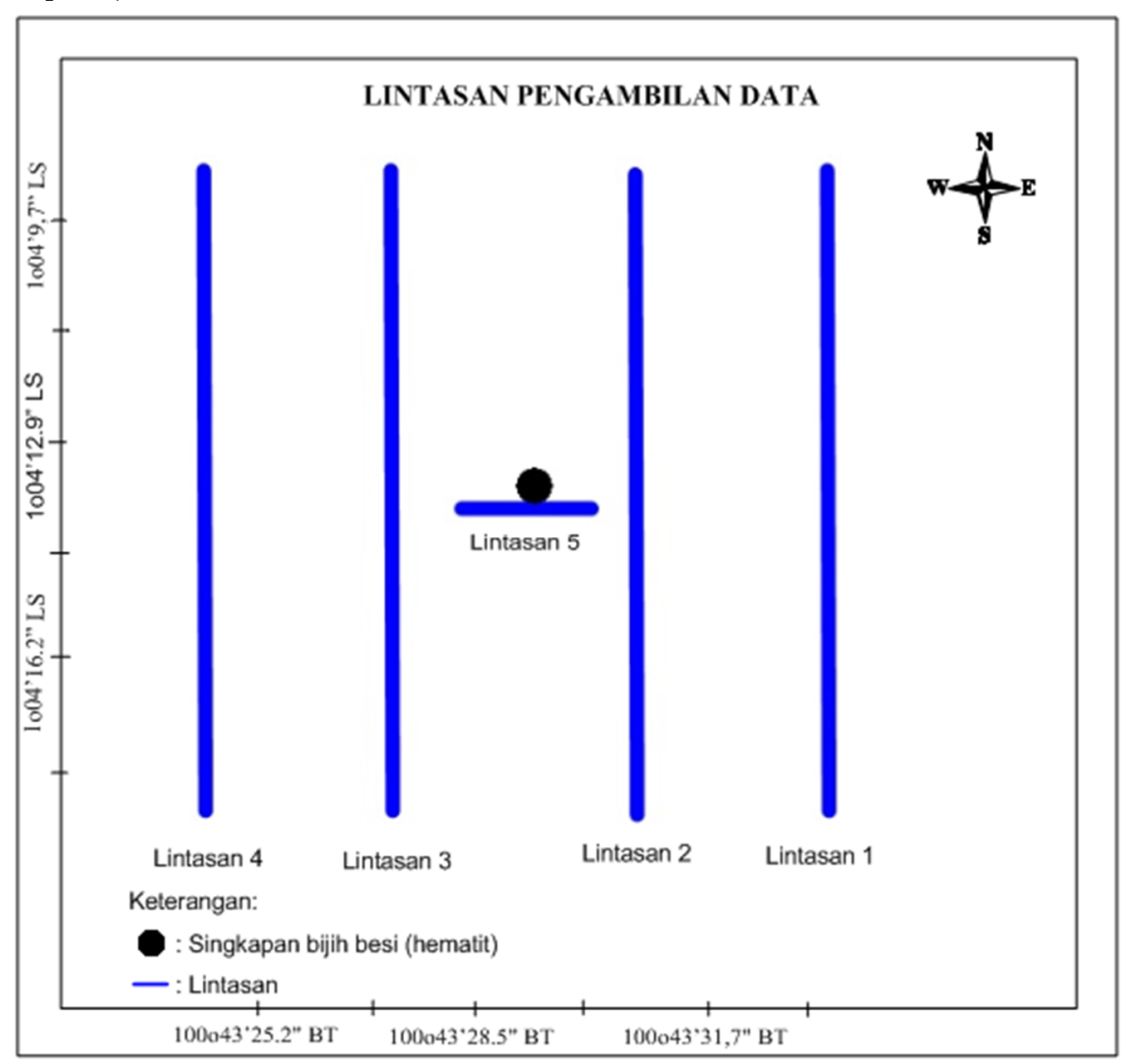

Gambar 1. Lintasan pengambilan data

Akuisisi data pada penelitian ini dilakukan secara looping yaitu pengukuran yang dimulai dari base station dan berakhir di base station lagi. Pengukuran looping ini hanya menggunakan satu alat Proton Magnetmeter (PMM) yang menjadi base dan rover (mobile). Pengukuran looping ini mencatat nilai variasi harian dan intensitas medan magnet total.

Lokasi base station terletak pada koordinat $01^{\circ} 03^{\prime} 55^{\prime \prime}$ LS, 10043'24,2” BT. Lokasi ini mempunyai nilai intensitas medan magnet bumi lokal berkisar antara 43030,34 nT 43047.45 nT. Selanjutnya, nilai intensitas medan magnet bumi diukur di setiap titik pada lintasan dengan spasi (jarak antar titik) pengukuran berjarak 4 meter. Pengukuran ini bertujuan untuk mencari nilai anomali intensitas medan magnet bumi yang disebabkan oleh mineral yang terdapat di bawah permukaan bumi.

Menurut Zaenudin dkk (2008) anomali magnetik di suatu tempat dipengaruhi oleh medan magnet observasi $\left(\mathrm{H}_{\mathrm{obs}}\right)$, medan magnet IGRF ( $\mathrm{H}_{\text {IGRF}}$ ), dan variasi medan magnet harian $\left(\mathrm{H}_{\mathrm{VH}}\right)$. Anomali tersebut diperoleh dengan mereduksi intensitas medan magnet hasil pengukuran di lapangan $\left(\mathrm{H}_{\mathrm{obs}}\right)$ dengan koreksi harian $\left(\mathrm{H}_{\mathrm{VH}}\right)$ dan koreksi IGRF. Koreksi harian bertujuan untuk mereduksi intensitas medan magnet luar, sedangkan koreksi IGRF bertujuan untuk mereduksi intensitas medan magnet utama. Anomali magnetik di suatu tempat dapat ditentukan berdasarkan Persamaan (Steven, 1999):

$$
\Delta H=H_{o b s}-H_{I G R F} \pm H_{V H}
$$

dengan:

$$
\begin{aligned}
& \Delta H=\text { medan magnet anomaly } \\
& H_{o b s}=\text { medan magnet observasi } \\
& H_{I G R F}=\text { medan magnet IGRF } \\
& H_{V H}=\text { medan magnet variasi harian }
\end{aligned}
$$

Hasil koreksi tersebut dapat direpresentasikan menggunakan peta kontur medan magnetik.

\subsection{Pemodelan Data}

Menurut Parasnis (1986) pemodelan sintetik dibuat berdasarkan pendekatan bentuk benda duga, yaitu berbentuk thin-sheet (tipis) dan tick- 
sheet (tebal). Pemodelan ini menggunakan software GEMLink dengan tampilan 2D. Input dari model ini adalah: deklinasi (D), inklinasi (I), intensitas magnetik, kedalaman (depth), suseptibilitas (k), dan dip (kemiringan). Berdasarkan data IGRF untuk daerah Gurun Datar memiliki sudut deklinasi $-0,2^{0}$, sudut inklinasi $-20,8833^{0}$, dan intensitas magnet total sebesar $42.922,70 \mathrm{nT}$.

\section{Hasil dan Pembahasan \\ 3.1 Anomali Medan Magnet}

Medan magnet anomali disebabkan oleh adanya mineral magnetik yang berada di bawah permukaan bumi maupun di sekitarnya. Berdasarkan penjelasan di atas untuk memperoleh anomali intensitas medan magnet, intensitas medan magnet hasil pengukuran di lapangan $\left(\mathrm{H}_{\mathrm{obs}}\right)$ harus direduksi dengan koreksi harian dan koreksi IGRF (Breiner, 1999). Hasil koreksi tersebut dapat direpresentasikan menggunakan peta kontur seperti terlihat pada Gambar 2.
Berdasarkan peta anomali kontur intensitas medan magnet tersebut, intensitas medan magnetik lokal di lokasi penelitian berkisar antara $-450 \mathrm{nT}$ sampai $150 \mathrm{nT}$. Nilai intensitas medan magnetik lokal yang dominan adalah antara -10 nT sampai $70 \mathrm{nT}$ yang ditunjukkan dengan warna kuning kecoklatan. Pada koordinat 1 ${ }^{\circ} 04^{\prime} 12,4^{\prime \prime}$ s.d 1 1०04'15,5” LS dan $100^{\circ} 43^{\prime 2} 28,6^{\prime \prime}$ s.d 100'43'30,3” BT terdapat daerah kontras dengan warna biru keunguan dengan nilai anomali intensitas medan magnetik lokal berkisar antara - $210 \mathrm{nT}$ sampai-450 nT.

Identifikasi sebaran bijih besi dan jenis batuannya secara vertikal dilakukan dengan memilih beberapa daerah yang memiliki kontras anomali medan magnet. Dari hasil pemetaan distribusi intensitas medan magnet lokal, maka ditentukan 5 lintasan anomali yang diwakili oleh 5 lintasan yaitu lintasan $A B$, lintasan $C D$, lintasan EF, lintasan $\mathrm{GH}$ dan lintasan IJ sebagaimana diperlihatkan pada Gambar 2.

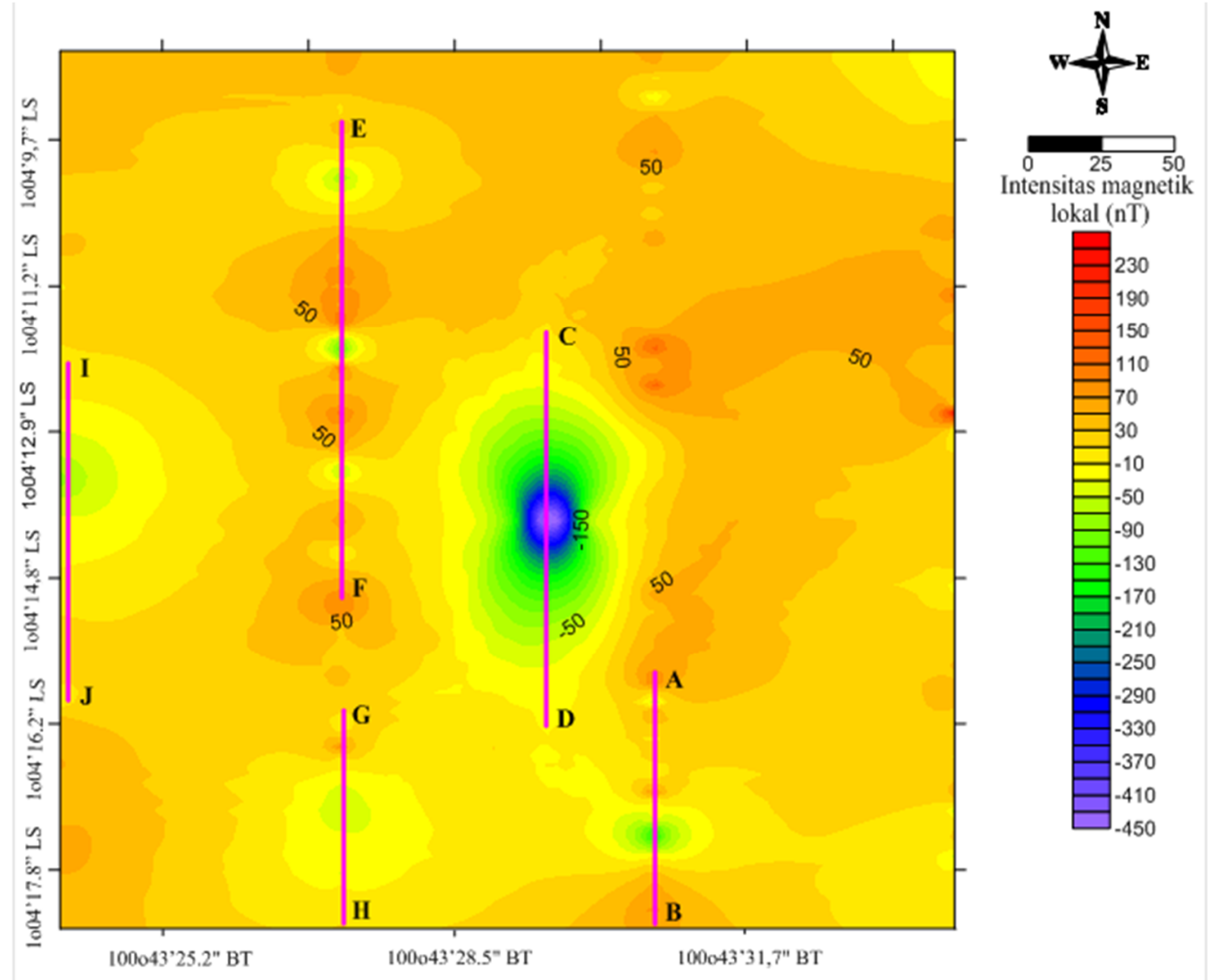

Gambar 2 Distribusi anomali medan magnet dan intasan-lintasan yang memotong daerah distribusi anomali intensitas magnet lokal

\subsubsection{Lintasan $\mathrm{AB}$}

Titik awal lintasan $\mathrm{AB}$ berada pada koordinat 1०04'15,2” LS 10043'30,7" BT dengan panjang lintasan 104,4 m membentang dari arah
Utara ke Selatan. Hasil pengolahan secara inversi dengan menggunakan software Mag2dc menghasilkan distribusi nilai suseptibilitas 
secara vertikal dengan nilai korelasi antara data observasi dan data kalkulasi sebesar 0,99 dapat dilihat pada Gambar 3. Berdasarkan Gambar 3, dapat diinterpretasikan bahwa terdapat 6 titik batuan mengandung bijih besi yang berada di sepanjang Lintasan AB. Jenis batuan dan posisi tiap titik batuan pada lintasan $\mathrm{AB}$ dapat dilihat pada Tabel 1. Dari Tabel 1, terlihat bahwa bijih besi yang terdapat pada lintasan $\mathrm{AB}$ adalah jenis batuan hematit dengan kedalaman yang bervariasi (2,1 meter s.d 30,8 meter). Pada jarak 70,8 meter s.d 78,5 meter dari titik A, terdapat urat mineral magnetit pada hematit.

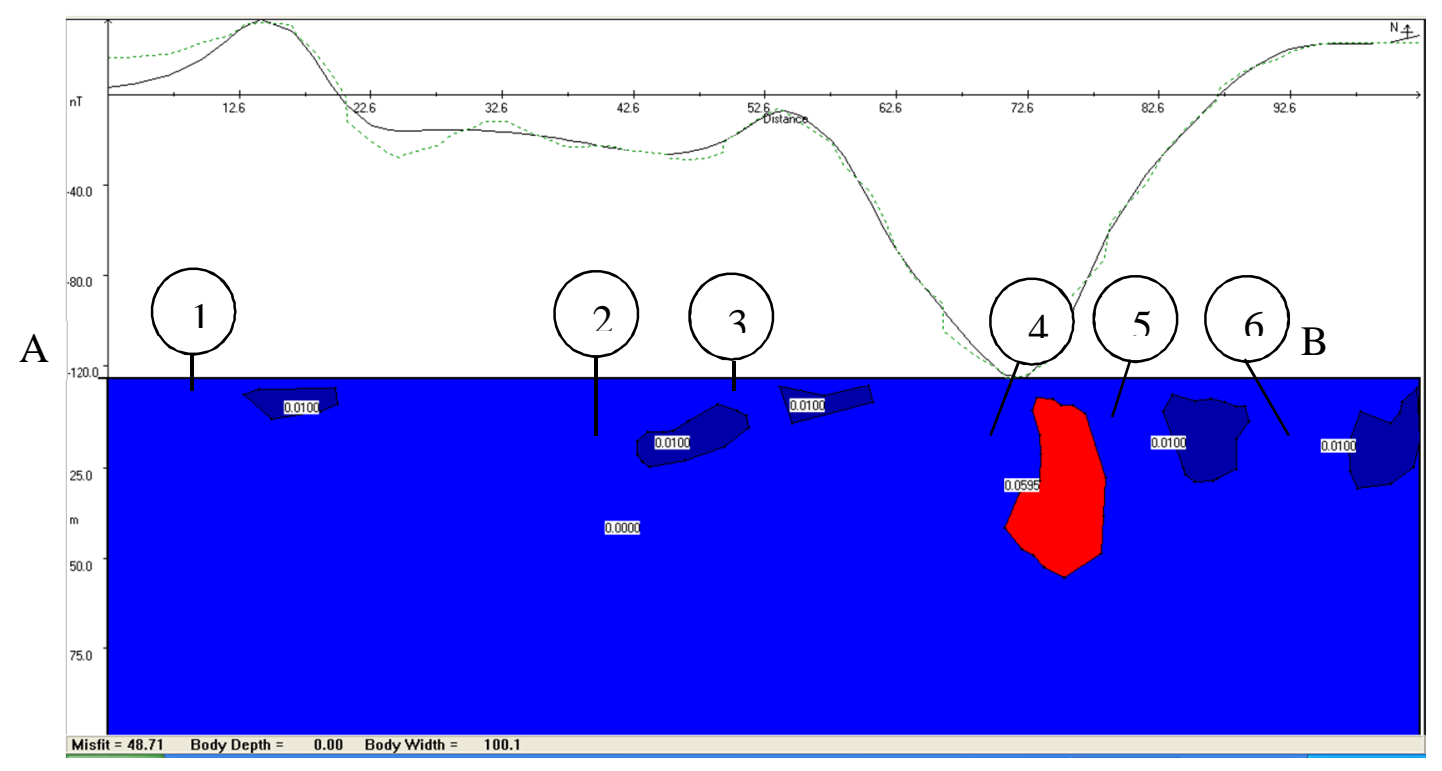

Gambar 3 Interpretasi penampang vertikal lintasan $A B$

Tabel 1. Posisi dan jenis batuan pada lintasan $\mathrm{AB}$

\begin{tabular}{|c|c|c|c|l|}
\hline No & $\begin{array}{c}\text { Jarak dari posisi } \\
\text { awal lintasan A } \\
\text { (meter) }\end{array}$ & $\begin{array}{c}\text { Kedalaman } \\
\text { (meter) }\end{array}$ & $\begin{array}{c}\text { Nilai } \\
\text { Suseptibilitas } \\
\text { (SI) }\end{array}$ & Jenis batuan \\
\hline 1 & 12,9 s.d 20,1 & 2,9 s.d 11,5 & 0,0100 & Hematit \\
\hline 2 & 42,8 s.d 51,4 & 7,5 s.d 25 & 0,0100 & Hematit \\
\hline 3 & 53,7 s.d 60,5 & 2,1 s.d 12,6 & 0,0100 & Hematit \\
\hline 4 & 70,8 s.d 78,5 & 5,6 s.d 55,6 & 0,0596 & $\begin{array}{l}\text { urat mineral } \\
\text { magnetit pada } \\
\text { hematit }\end{array}$ \\
\hline 5 & 82,7 s.d 69,4 & 4,7 s.d 29 & 0,0100 & Hematit \\
\hline 6 & 97,0 s.d 102,2 & 3,0 s.d 30,8 & 0,0100 & Hematit \\
\hline
\end{tabular}

\subsubsection{Lintasan CD}

Titik awal lintasan CD terletak pada koordinat 1004'11,8” LS dan 100'43'29,5” BT dengan panjang lintasan 128,7 m membentang Utara ke Selatan. Hasil pengolahan secara inversi dengan menggunakan software Mag2dc menghasilkan distribusi nilai suseptibilitas secara vertikal dengan nilai korelasi antara data observasi dan data kalkulasi sebesar 0,99 dapat dilihat pada Gambar 4. 


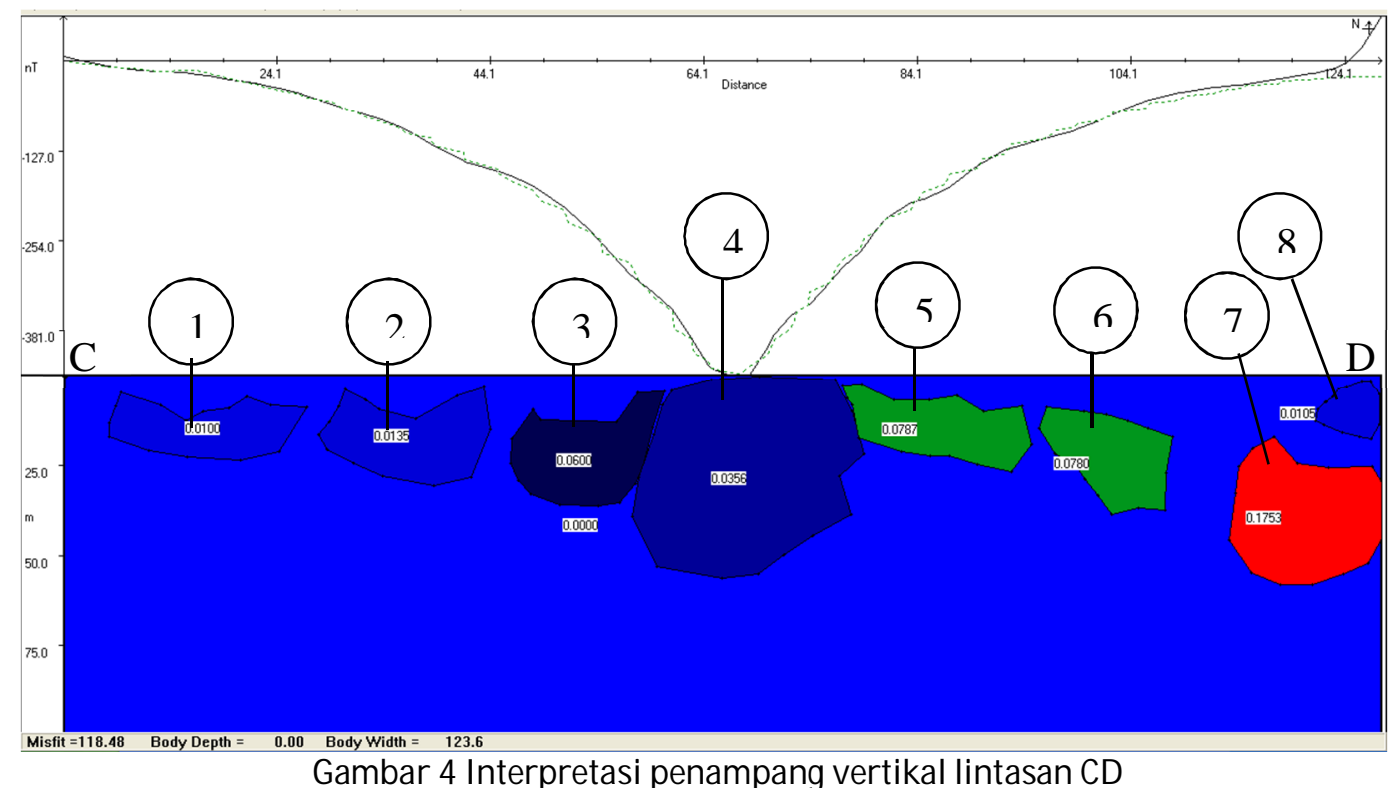

Berdasarkan Gambar 4 dapat lintasan CD. Jenis batuan dan posisi tiap titik diinterpretasikan bahwa terdapat 8 titik batuan batuan pada lintasan CD dapat dilihat pada mengandung bijih besi yang berada di sepanjang

Tabel 2.

Tabel 2. Posisi dan jenis batuan pada lintasan CD

\begin{tabular}{|c|c|c|c|l|}
\hline No & $\begin{array}{c}\text { Jarak dari posisi } \\
\text { awal lintasan C } \\
\text { (meter) }\end{array}$ & $\begin{array}{c}\text { Kedalaman } \\
\text { (meter) }\end{array}$ & $\begin{array}{c}\text { Nilai } \\
\text { Suseptibilitas } \\
\text { (SI) }\end{array}$ & Jenis batuan \\
\hline 1 & 8,4 s.d 26,9 & 4,7 s.d 23,7 & 0,0100 & hematit \\
\hline 2 & 28,0 s.d 44,2 & 3,2 s.d 30,8 & 0,0135 & hematit \\
\hline 3 & 46,0 s.d 60,4 & 4,4 s.d 36,4 & 0,0600 & $\begin{array}{l}\text { urat mineral } \\
\text { magnetit pada } \\
\text { hematit }\end{array}$ \\
\hline 4 & 57,4 s.d 79,1 & 0,3 s.d 56,5 & 0,0356 & hematit \\
\hline 5 & 77,1 s.d 94,8 & 2,7 s.d 26,9 & 0,0787 & $\begin{array}{l}\text { urat mineral } \\
\text { magnetit pada } \\
\text { hematit }\end{array}$ \\
\hline 6 & 95,5 s.d 107,9 & 8,9 s.d 38,7 & 0,0780 & $\begin{array}{l}\text { urat mineral } \\
\text { magnetit pada } \\
\text { hematit }\end{array}$ \\
\hline 7 & 113,2 s.d 129,4 & 17,2 s.d 58,3 & 0,1753 & $\begin{array}{l}\text { urat mineral } \\
\text { magnetit pada } \\
\text { hematit }\end{array}$ \\
\hline 8 & 121,4 s.d 127,4 & 1,3 s.d 17,6 & 0,0105 & hematit \\
\hline
\end{tabular}

Dari Gambar 2 dan Tabel 2, terlihat bahwa pada lintasan CD diduga terdapat jenis batuan urat mineral magnetit hematit yang terpusat di tengah lintasan CD yang tersebar dari jarak 46 s.d 129,4 dari titik C. Dari Tabel 2, terdapat material bijih besi jenis hematit yang berada pada kedalaman yang sangat dangkal $(30 \mathrm{~cm}$ dari permukaan).

\subsubsection{Lintasan EF}

Titik awal lintasan EF terletak pada koordinat 1०04'09,4" LS 10043'27,3" BT dengan panjang lintasan 186,3 m membentang Utara ke Selatan. Hasil pengolahan secara inversi dengan menggunakan software Mag2dc menghasilkan distribusi nilai suseptibilitas secara vertikal dengan nilai korelasi antara data observasi dan 
data kalkulasi sebesar 0,97 dapat dilihat pada Gambar 5.

Dari Gambar 5, dapat diinterpretasikan bahwa terdapat 9 titik batuan mengandung bijih besi yang berada di sepanjang lintasan EF. Jenis batuan dan posisi tiap titik batuan pada lintasan
EF dapat dilihat pada Tabel 3. Dari Tabel 3, diduga terdapat material bijih besi jenis hematit sepanjang lintasan EF dengan kedalaman yang bervariasi (0,6 s.d 44,1 meter dari permukaan).

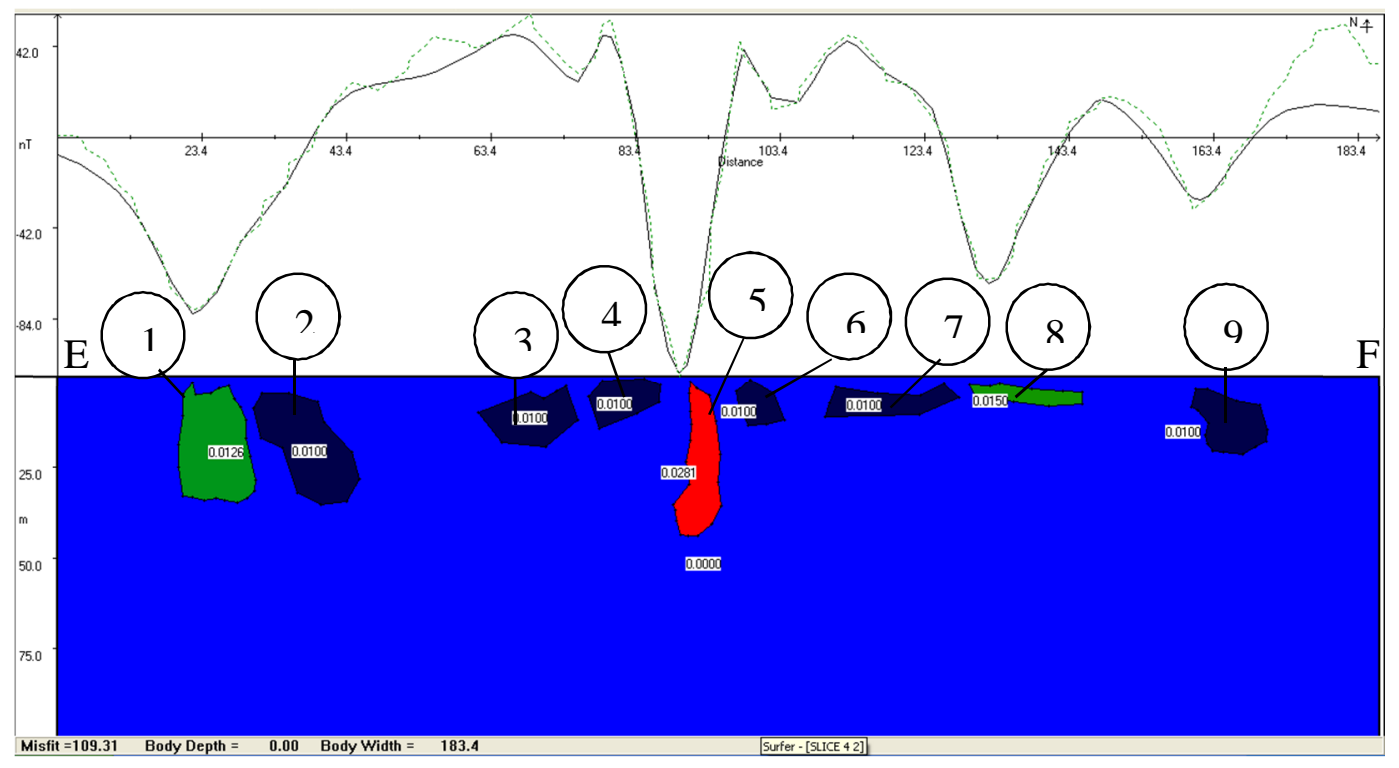

Gambar 5 Interpretasi penampang vertikal lintasan EF

Tabel 3. Posisi dan jenis batuan pada lintasan EF

\begin{tabular}{|c|c|c|c|l|}
\hline No & $\begin{array}{c}\text { Jarak dari posisi } \\
\text { awal lintasan } \mathbf{1} \\
\text { (meter) }\end{array}$ & $\begin{array}{c}\text { Kedalaman } \\
\text { (meter) }\end{array}$ & $\begin{array}{c}\text { Nilai } \\
\text { Suseptibilitas } \\
\text { (SI) }\end{array}$ & Jenis batuan \\
\hline 1 & 20,5 s.d 30,8 & 1,8 s.d 34,9 & 0,0126 & hematit \\
\hline 2 & 30,5 s.d 45,1 & 4,7 s.d 35,5 & 0,0100 & hematit \\
\hline 3 & 61,6 s.d 73,4 & 2,7 s.d 19,5 & 0,0100 & hematit \\
\hline 4 & 76,8 s.d 86,7 & 0,6 s.d 14,5 & 0,0100 & hematit \\
\hline 5 & 88,5 s.d 95,3 & 1,5 s.d 44,1 & 0,0281 & hematit \\
\hline 6 & 97,4 s.d 104,0 & 0,9 s.d 13,6 & 0,0100 & hematit \\
\hline 7 & 110,2 s.d 128,1 & 2,1 s.d 11,2 & 0,0100 & hematit \\
\hline 8 & 129,5 s.d 145,2 & 2,1 s.d 8,3 & 0,0150 & hematit \\
\hline 9 & 160,2 s.d 170,8 & 3,7 s.d 21,7 & 0,0100 & hematit \\
\hline
\end{tabular}

\subsubsection{Lintasan GH}

Titik awal lintasan GH terletak pada koordinat 1'04'15,9' LS dan 100'43'27,3” BT dengan panjang lintasan 77,6 m membentang Utara ke Selatan. Hasil pengolahan secara inversi dengan menggunakan software Mag2dc menghasilkan distribusi nilai suseptibilitas secara vertikal dengan nilai korelasi antara data observasi dan data kalkulasi sebesar 0,84 dapat dilihat pada Gambar 6. 


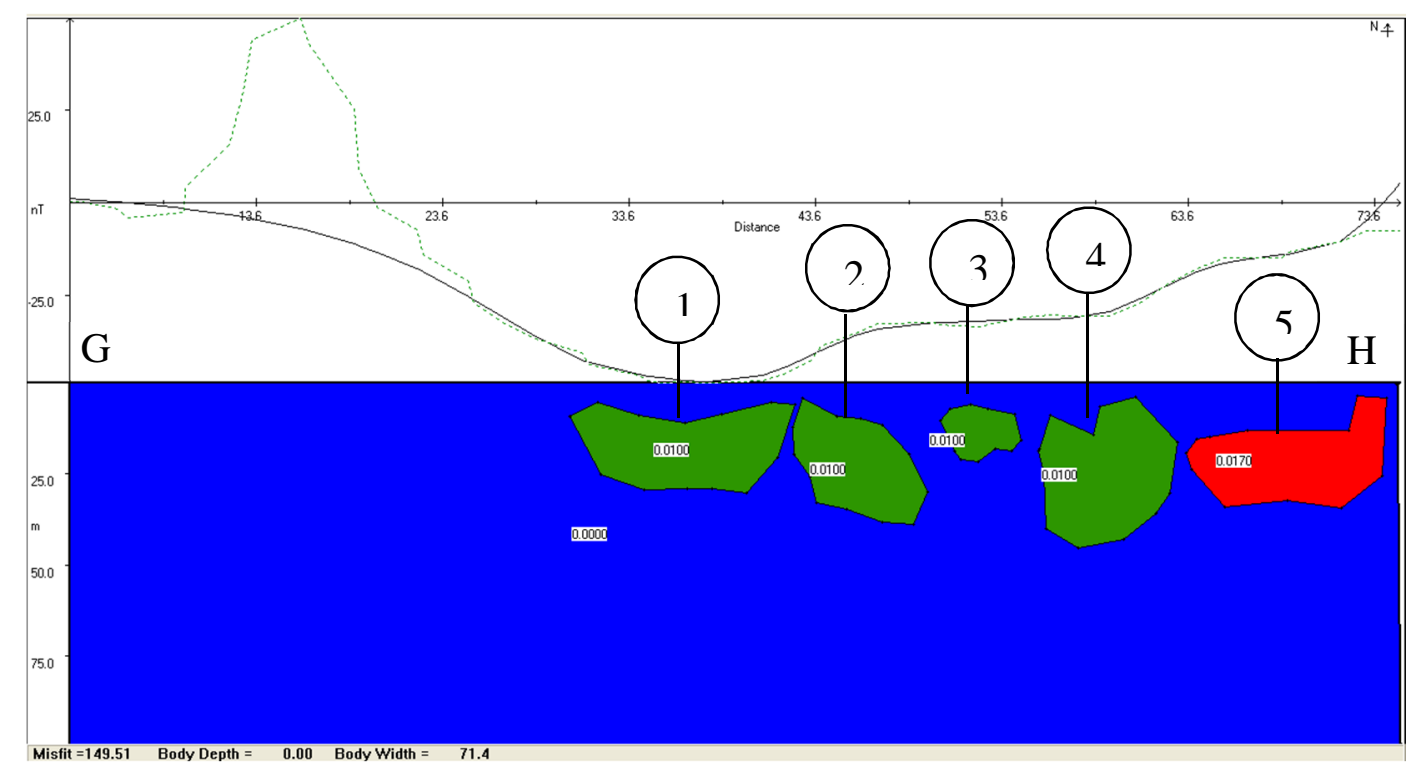

Gambar 6 Interpretasi penampang vertikal lintasan GH

Tabel 4. Posisi dan jenis batuan pada lintasan GH

\begin{tabular}{|c|c|c|c|l|}
\hline No & $\begin{array}{c}\text { Jarak dari posisi } \\
\text { awal lintasan G } \\
\text { (meter) }\end{array}$ & $\begin{array}{c}\text { Kedalaman } \\
\text { (meter) }\end{array}$ & $\begin{array}{c}\text { Nilai } \\
\text { Suseptibilitas } \\
\text { (SI) }\end{array}$ & Jenis batuan \\
\hline 1 & 30,5 s.d 42,2 & 5,6 s.d 30,5 & 0,0100 & hematit \\
\hline 2 & 42,4 s.d 49,6 & 4,4 s.d 39,1 & 0,0100 & hematit \\
\hline 3 & 50,3 s.d 54,6 & 7,3 s.d 21,7 & 0,0100 & hematit \\
\hline 4 & 70,8 s.d 78,5 & 5,6 s.d 55,6 & 0,0596 & hematit \\
\hline 5 & 82,7 s.d 69,4 & 4,7 s.d 29 & 0,0170 & hematit \\
\hline
\end{tabular}

Berdasarkan Gambar 6 dapat diinterpretasikan bahwa terdapat 5 titik batuan mengandung bijih besi yang berada di sepanjang lintasan GH. Jenis batuan dan posisi tiap titik batuan pada lintasan GH dapat dilihat pada Tabel 4. Hasil interpretasi nilai suseptibilitas pada lintasan GH pada Tabel 4, menunjukkan bahwa material bijih besi pada lintasan $\mathrm{GH}$ adalah jenis hematit seperti pada lintasan EF.

\section{Kesimpulan}

Bijih hematit $\left(\mathrm{Fe}_{2} \mathrm{O}_{3}\right)$ diduga terdapat pada lintasan $A B$ dengan suseptibilitas 0,0100 SI, lintasan CD dengan suseptibilitas berkisar antara 0,0100 s.d 0.0356 SI, lintasan EF dengan suseptibilitas berkisar antara 0,0100 s.d 0.0281 SI, lintasan GH dengan suseptibilitas berkisar antara 0,0100 s.d 0.0170 SI, dan lintasan IJ dengan suseptibilitas berkisar antara 0,0100 s.d 0.0175 SI.

Urat mineral magnetit $\left(\mathrm{Fe}_{3} \mathrm{O}_{4}\right)$ pada hematit $\left(\mathrm{Fe}_{2} \mathrm{O}_{3}\right)$ diduga terdapat pada lintasan $A B$ dengan suseptibilitas $0,0595 \mathrm{SI}$, dan lintasan
CD dengan suseptibilitas berkisar antara 0,0600 $-0,1753$ SI.

\section{Daftar Pustaka}

Badan Nasional Penanggulangan Bencana, Peta Wilayah Administratif Kabupaten Solok.

Breiner, S., 1999, Aplication Manual For Portabel Magnetometers, Geomatrics, San Jose California USA.

Idral, A., 2008, Aplikasi Metoda Geomagnetik Dalam Menentukan Potensi Sumber Daya Biji Besi di Daerah Bukit Bakar dan Ulu Rabau, Kecamatan Lembah Gumanti Kab. Solok, Sumatra Barat, Buletin Sumber Daya Geologi, Volume 3 No. 3, 2008.

Mufit, F., Fadhillah, H. Amir, S. Bijaksana, 2006, Kajian Sifat Magnetik Pasir Besi Pantai Sunur, Pariaman, Sumatera Barat, Jurnal Geofisika 2006/1. 
Parasnis, D.S. 1986, Principles of Applied Geophysics $4^{\text {th }}$ Edition, 3-9. Chapman and Hall.

Steven, M. A., 1999, Magnetic Field Measurement, CRC Press LLC.

Zaenudin, A., J.T. Ramses, Rahmat, S. M., 2008, "Eksplorasi Bii Besi (Iron Ore) Dengan Metode Magnetik", Prosiding Seminar Nasional Sains dan Teknologi-II 2008, 17-18 November 2008, Universitas Lampung. 